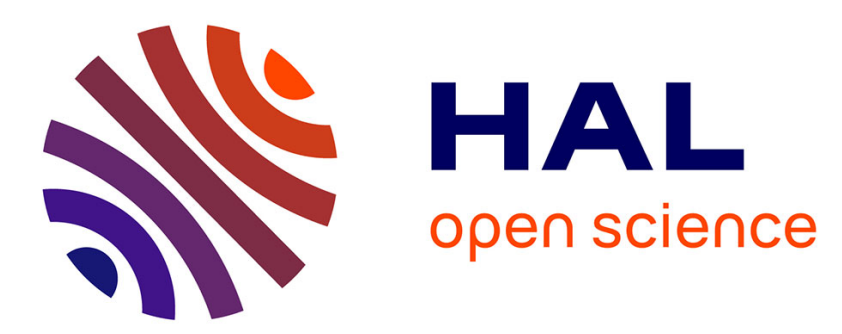

\title{
Modalities and characteristics of human occupations in Yemen during the Early/Mid-Holocene \\ Rémy Crassard
}

\section{To cite this version:}

Rémy Crassard. Modalities and characteristics of human occupations in Yemen during the Early/MidHolocene. Comptes Rendus Géoscience, 2009, 341 (8-9), pp.713 - 725. 10.1016/j.crte.2009.05.003 . hal-01828467

\section{HAL Id: hal-01828467 https://hal.science/hal-01828467}

Submitted on 2 Sep 2018

HAL is a multi-disciplinary open access archive for the deposit and dissemination of scientific research documents, whether they are published or not. The documents may come from teaching and research institutions in France or abroad, or from public or private research centers.
L'archive ouverte pluridisciplinaire HAL, est destinée au dépôt et à la diffusion de documents scientifiques de niveau recherche, publiés ou non, émanant des établissements d'enseignement et de recherche français ou étrangers, des laboratoires publics ou privés. 


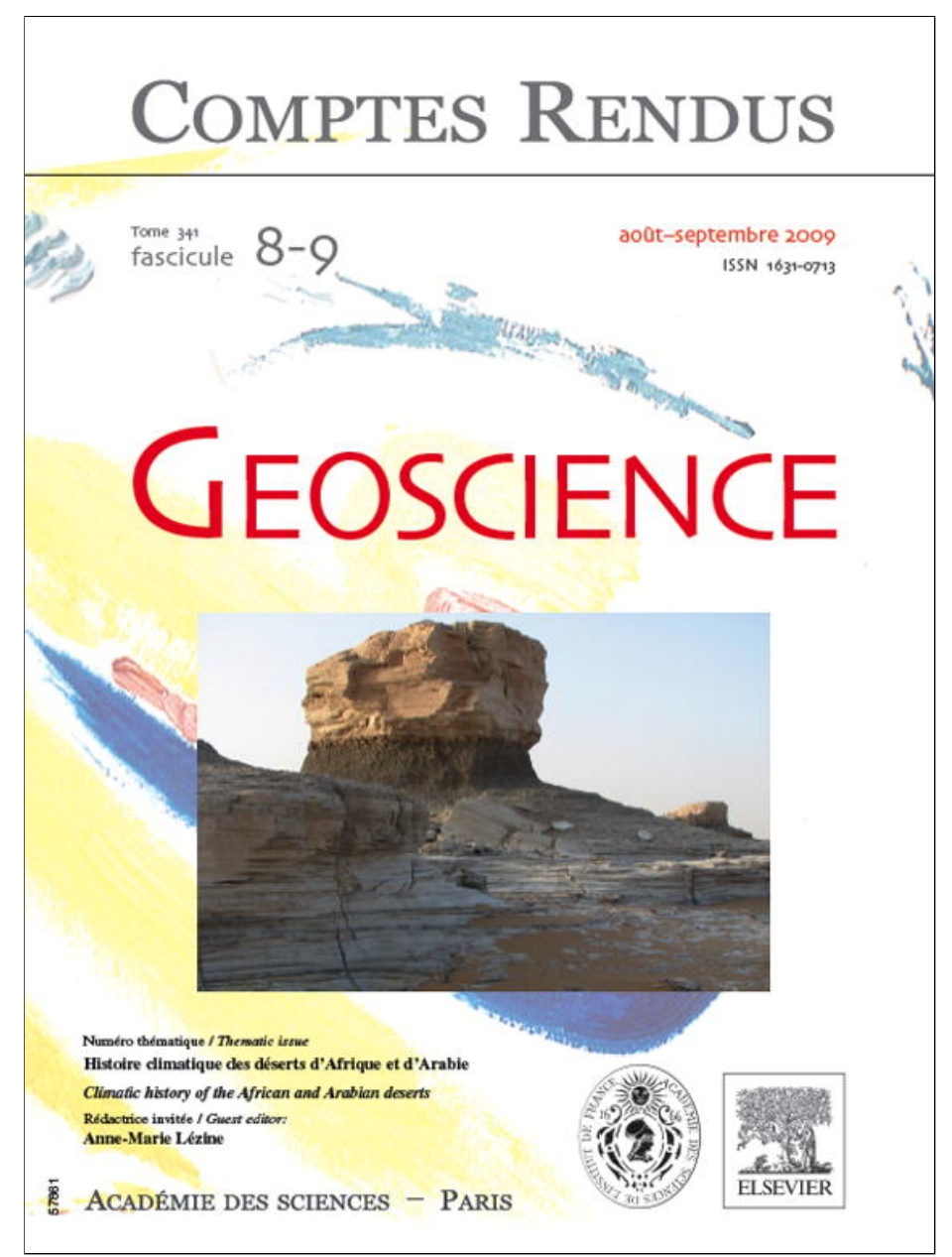

This article appeared in a journal published by Elsevier. The attached copy is furnished to the author for internal non-commercial research and education use, including for instruction at the authors institution and sharing with colleagues.

Other uses, including reproduction and distribution, or selling or licensing copies, or posting to personal, institutional or third party websites are prohibited.

In most cases authors are permitted to post their version of the article (e.g. in Word or Tex form) to their personal website or institutional repository. Authors requiring further information regarding Elsevier's archiving and manuscript policies are encouraged to visit:

http://www.elsevier.com/copyright 


\title{
Modalities and characteristics of human occupations in Yemen during the Early/Mid-Holocene
}

\author{
Rémy Crassard \\ Leverhulme Centre for Human Evolutionary Studies, University of Cambridge, The Henry Wellcome Building, \\ Fitzwilliam Street, CB2 1QH Cambridge, United Kingdom \\ Received 24 April 2009; accepted after revision 18 May 2009 \\ Available online 29 July 2009
}

Written on invitation of the Editorial Board

\begin{abstract}
Although few reference sites are known in Yemen, those found to date give good, although preliminary, chronostratigraphic sequences that demonstrate different types of lithic industries. The Hadramawt region of eastern Yemen is particularly rich in Early to Mid-Holocene sites. These sites are characterized by the appearance of laminar and especially bifacial lithic industries. The latter includes the production of flat as well as symmetrical arrowheads, and likely later manufacture of arrowheads with triangular section. The distribution of the trihedral points through southern Arabia suggests a technical tradition anchored at the beginning of the Middle Holocene. Presence of the fluting technique reinforces the impression that a true local Arabian "endemic development area" was constituted through time, without any particular external influences. Climate and geography probably contributed to settling modalities and consequently influenced diffusions, relations and movements of populations. To cite this article: $R$. Crassard, C. R. Geoscience 341 (2009).
\end{abstract}

C) 2009 Académie des sciences. Published by Elsevier Masson SAS. All rights reserved.

\section{Résumé}

Modalités et caractéristiques des occupations humaines à l'Holocène ancien/moyen au Yémen. Encore peu de sites de référence sont connus au Yémen, mais ceux retrouvés jusqu'à présent permettent de proposer des premières séquences chronostratigraphiques qui situent dans le temps différents types d'industries lithiques : la région du Hadramawt, à l'Est du Yémen, est une région particulièrement riche en vestiges Holocène ancien/moyen. Cette période est caractérisée par l'apparition d'industries lithiques, probablement laminaires, mais surtout bifacial, avec une production importante d'armatures plates à pédoncule et ailerons et une, vraisemblablement postérieure, d'armatures à section triédrique. La répartition de cette dernière à travers l'Arabie du Sud suggère une tradition technique bien ancrée au début de l'Holocène moyen et particulière à cette région. La présence du flûtage contribue à renforcer cette impression qu'une véritable « zone de développement endémique » s'est constituée au cours du temps, sans que des influences extérieures particulières n'interfèrent au sein des traditions locales d'Arabie. Le climat et l'orographie ont vraisemblablement contribué à certains types d'installations et, en conséquence, influencé les courants de diffusions, de relations et de mouvements de populations. Pour citer cet article : R. Crassard, C. R. Geoscience 341 (2009).

(C) 2009 Académie des sciences. Publié par Elsevier Masson SAS. Tous droits réservés.

Keywords: Holocene; Yemen; Neolithic; Lithic technology; Arabian Humid Period

Mots clés : Holocène ; Yémen ; Néolithique ; Technologie lithique ; Période humide arabe

E-mail addresses: rc461@cam.ac.uk, rcrassard@prehistoricyemen.com.

1631-0713/\$ - see front matter (C) 2009 Académie des sciences. Published by Elsevier Masson SAS. All rights reserved. doi:10.1016/j.crte.2009.05.003 


\section{Yemen as a key place for regional prehistoric research}

From the Pleistocene to the Early and MidHolocene, Southwest Arabia (Fig. 1) is considered a potential crossing point between Africa, the Levant and the rest of Asia. Its strategic geographic position prompts debates on topics as varied as the exit of Africa by the first hominids and modern humans [3,5,31, 40,47], the diffusion of the Levallois concept during the Middle Palaeolithic [25,30,33,48,51], and the networks of influence between the Neolithic cradles and their peripheries [2,18,27,37].

Currently palaeoenvironmental and more specifically palaeoclimatic data refine our knowledge of prehistoric occupations. Wet phases set within a context nowadays dominated by aridity suggests favourable periods for the settlement of prehistoric societies during the Pleistocene $[6,44,45,52,59]$. During the Holocene, humidity reached its maximum [53] during the Arabian Humid Period [38,42] (7500-5500 BC Cal). This period is highlighted by the evolution of the monsoons described by analyses of palaeosols, palaeolakes or speleothems [15,32,41,42,49,50,53,54].

When compared to Europe and the Levant, prehistoric research in Yemen is a recent phenomenon. Until recently, archaeological research simply dealt with general questions of prehistoric occupation in Yemen, even though old settlements were very quickly recognized [1,7,36,56]. Consequently, some people regard southern Arabia as a cul-de-sac, not only geographically, but also culturally [22,34]. The recent focus on this area is generating a refined chronocultural framework and demonstrating a much less negative image.

\section{Surface and stratified sites in Yemen}

For several decades, Yemen has been revealing a significant number of lithic industries, datable to the Pleistocene and the Holocene. In some cases, their origins are known with precision, and in others, completely ignored or poorly understood. These industries almost always come from surface sites, as climatic and erosional processes cause a partial or total destruction of sediment cover. Heavy objects, including a large number of knapped stone, remain in place after loose material is scoured away. Thus, while deflation sometimes allows easy site discovery, it also leads to the destruction of the archaeological context. Dating, whether it is absolute (chronometric) or relative is then made difficult.

In recent years, the discovery of Holocene sites with preserved sedimentary accumulation has more than doubled the information of known, prehistoric stratigraphies in Yemen. These sites, such as Manayzah [28], HDOR 410 and HDOR 419 [26,29], Khuzmum [23,46] and GBS [23,57], are all located in the Hadramawt of

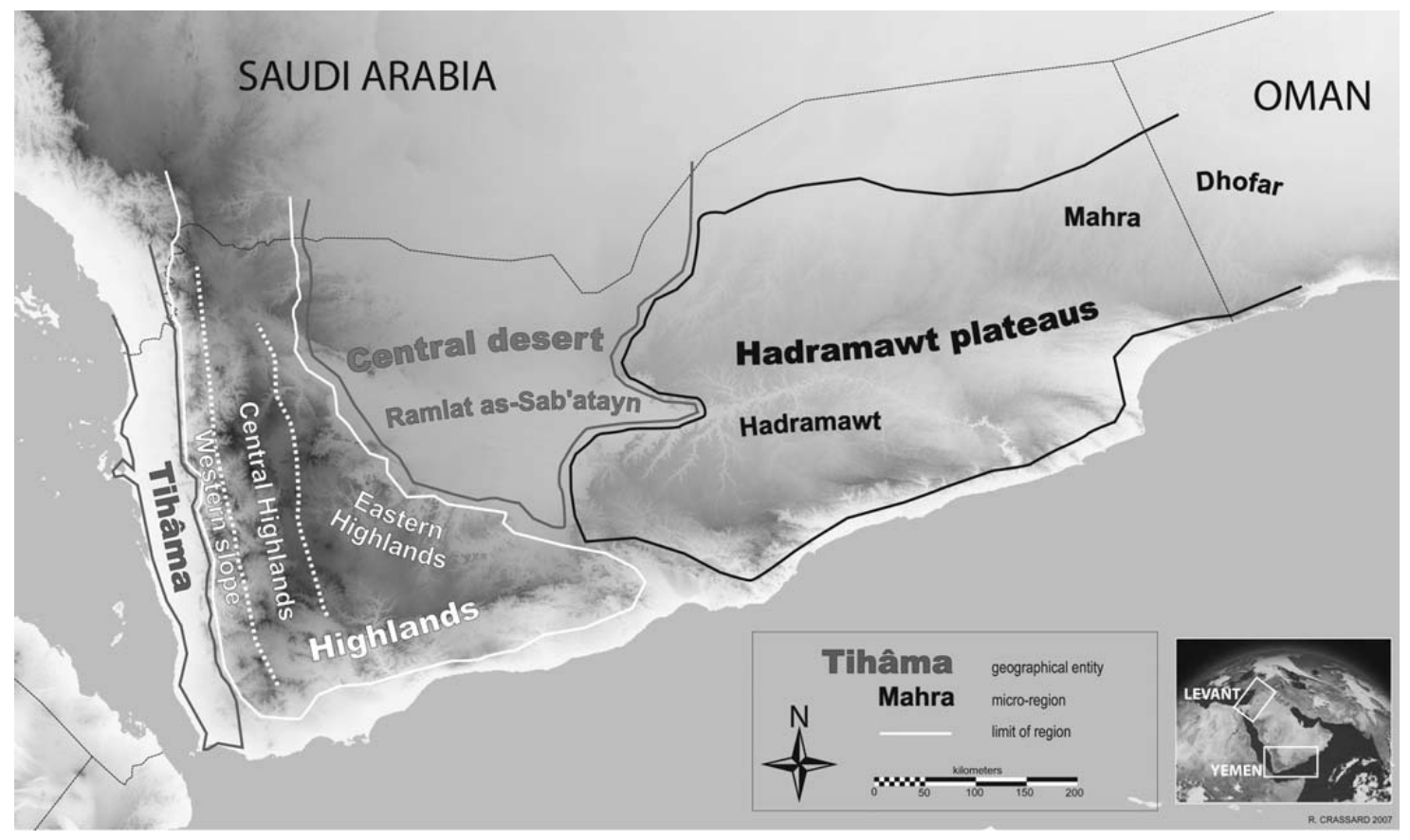

Fig. 1. Geographical entities in Yemen.

Fig. 1. Entités géographiques du Yémen. 


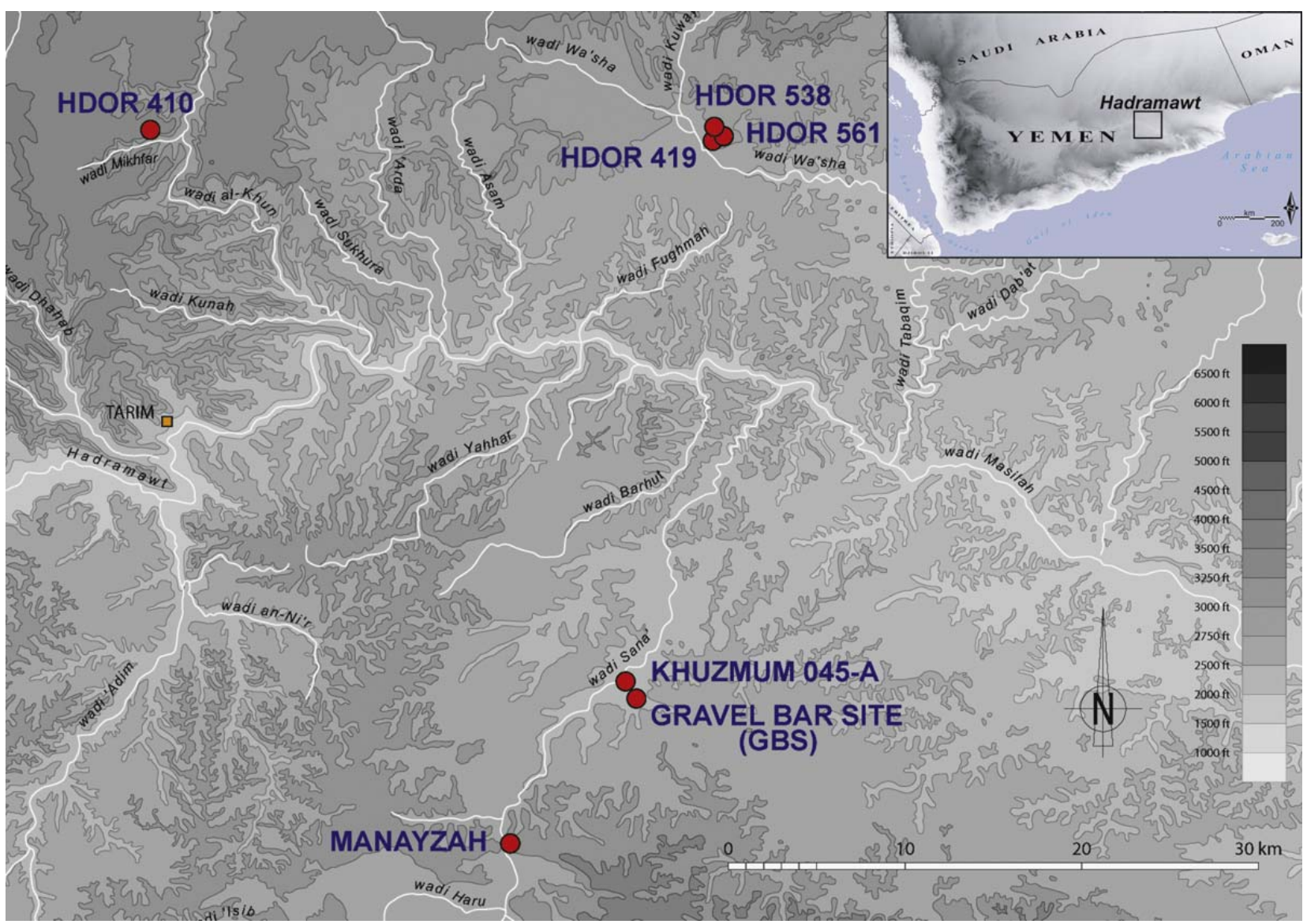

Fig. 2. Stratified sites in central Hadramawt.

Fig. 2. Sites stratifiés du Hadramawt central.

eastern Yemen (Fig. 2). This geographical entity proves to be a particularly favourable area to improve our understanding of old and recent prehistory, as many sites from various periods have been identified there during intensive, systematic surveys [23].

\section{The local peculiarities of lithic technology in Early/Mid-Holocene South Arabia and its comparison with the Levant}

\subsection{Stratified and surface sites joined together by the study of lithic industries}

Because of the use of pressure retouch in shaping arrowheads, an intellectual shortcut led archaeologists to regularly associate the presence of these tools in South Arabia with the prepottery Neolithic in the Near and Middle-East (including the 'Fertile Crescent'). The contribution of recent data leads us to modify the situation in Yemen. The discovery of techniques specific to the Yemeni territory during the Holocene suggests that local populations were not in direct contact with contemporary human groups of the
Levantine regions. From the 8th to the 5th millennium $\mathrm{BC}$, typical techniques from Yemen include the use of fluting, now well-known but considered for a long time as exclusively present in the Palaeoindian societies of the American continent during the extreme end of the Pleistocene and the beginning of the Holocene $[16,28]$.

Fluting (Fig. 3:1-3) is, for instance, very well illustrated at the site of Manayzah in Wadi Sanâ [28]. This Early to Mid-Holocene site is exceptional for its deep and well-preserved occupational stratigraphy. Here, an unparalleled corpus of stone tools, animal bone, and clearly defined activity and dwelling areas, as well as elements of stone and shell jewellery are found. Lithic industries are widely diversified with worked obsidian, bifacial arrowheads, and numerous other tool types. The fluting technique appears in stratigraphy and is now dated to the first half of the 6th millennium BC by radiocarbon assay on associated organic material (Table 1; for a complete inventory of radiocarbon dates from Yemen see [23], pp. 46-48). The technique involves extracting a flake longitudinally along the axis of the piece from one of its extremities, mainly from the point in Arabia [16]. The characteristic waste of this 


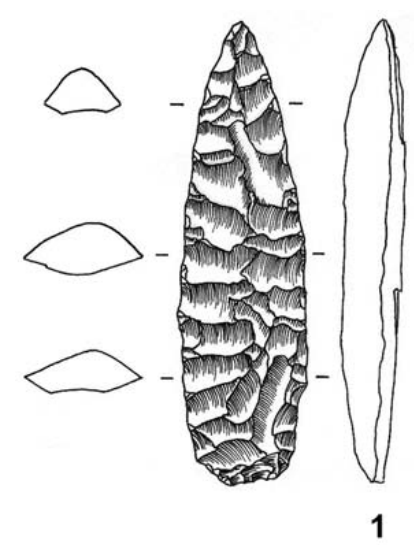

1
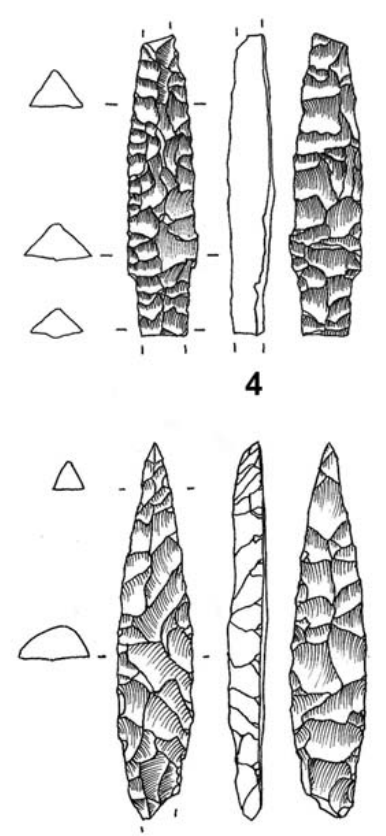

8
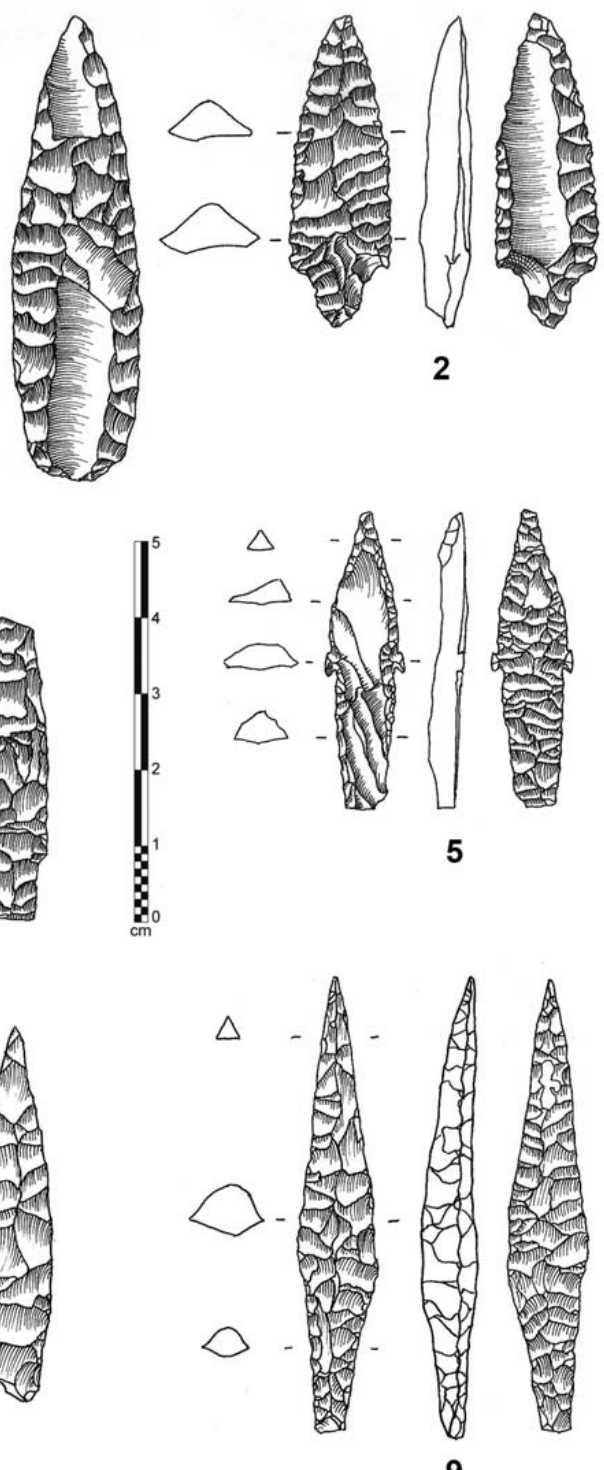
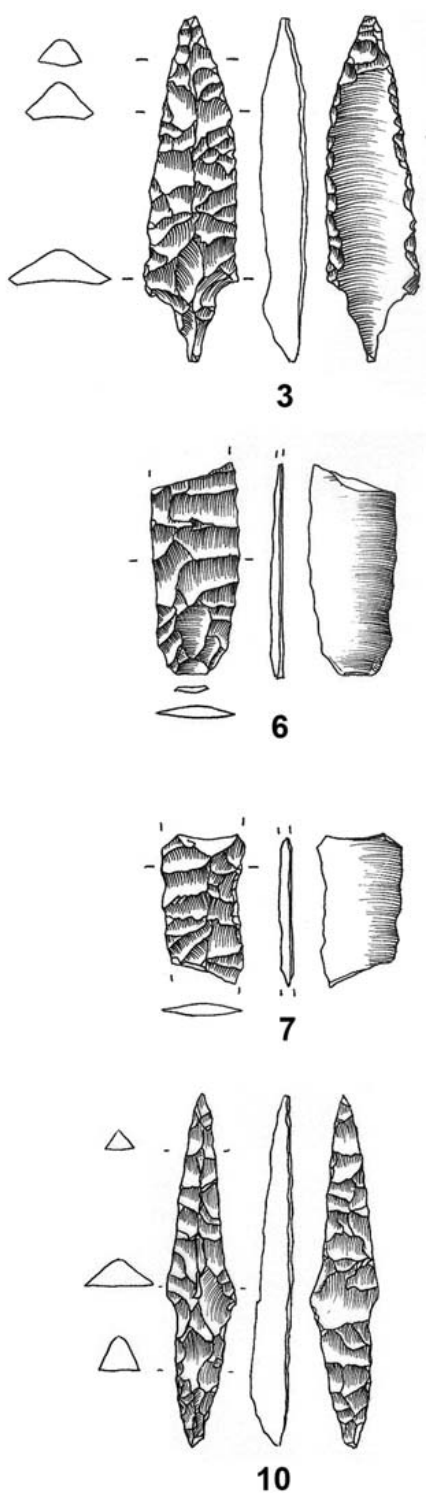

Fig. 3. Lithic industry from Manayzah: 1-3: fluted points; 4,5: trihedral points; 6,7: channel-flakes. Trihedral points from Hadramawt: 8: HDOR 410; 9 HDOR 419; 10 Khuzmum 045-A (drawings J. Espagne).

Fig. 3. Industrie lithique de Manayzah : 1-3 : pointes flûtes ; 4,5 : pointes triédriques ; $6,7:$ chutes de flûtage. Pointes triédriques du Hadramawt : 8 : HDOR 410 ; 9: HDOR 419 ; 10 : Khuzmum 045-A (dessins J. Espagne).

production ("channel-flakes", Fig. 3:6,7) were found on the site itself in Manayzah, proving that this technique was implemented by the occupants of the site. Manayzah is also exceptional since it is a rare example of a stratified site delivering faunal remains in great quantity. Fauna are present in most of the layers excavated to date. According to initial results, it seems that the first indices of animal domestication may appear in the 6th millennium BC [43].

In addition, several technical schemes and modes of lithic production, unknown or little documented until now, were discerned in the Hadramawt region. The description of the Wa'shah debitage method $[24,26]$, which is only present on the surface of Wadi Wa'shah and Wadi Sanâ plateaus, marks an important stage in the definition of a chronocultural framework for South Arabian prehistory (Fig. 4). The existence of this predetermined mode of pointed blade production affirms with certainty the presence of prehistoric populations using a laminar technology. This method, while being very close to the Levallois debitage concept, takes place only on laminar volumetric structures, and not from a flat surface. Its precise dating is still unknown even though some laminar indices are found in stratigraphy, in particular at HDOR 419 [29]. At this point, only a vague date can be 
Table 1

Dating of the various layers.

Tableau 1

Datation des couches.

\begin{tabular}{|c|c|c|c|c|c|}
\hline Site/Layer & Nature & $\begin{array}{l}\text { Laboratory } \\
\text { reference }\end{array}$ & $\begin{array}{l}{ }^{14} \mathrm{C} \text { age } \\
\mathrm{BP}\end{array}$ & $\begin{array}{l}1 \sigma \text { calibrated } \\
\text { age } \mathrm{BC}\end{array}$ & $\begin{array}{l}\text { Bibliographic } \\
\text { reference }\end{array}$ \\
\hline HDOR 410 (A5 Niv 3 Fy 7) & Charcoal & AA64365 & $6030 \pm 56$ & $4993-4848$ & Crassard [23] \\
\hline HDOR 410 (Niv 4 prox Fy 12) & Charcoal & AA64369 & $6389 \pm 58$ & $5466-5318$ & Crassard [23] \\
\hline HDOR 410 (B5 Niv 4 Fy 12) & Charcoal & AA64368 & $6651 \pm 50$ & $5625-5544$ & Crassard [23] \\
\hline Manayzah (K9-Hearth1) & Charcoal & AA59570 & $6902 \pm 41$ & $5835-5733$ & Crassard et al. [28] \\
\hline HDOR 419 (A13 Niv 5 b) & Charcoal & AA64360 & $6931 \pm 48$ & $5872-5743$ & Crassard [23] \\
\hline Manayzah (114 C 009-10) & Charcoal & AA66684 & $6981 \pm 51$ & $5973-5802$ & Crassard [23] \\
\hline Manayzah (L9 A 010-15) & Charcoal & AA66683 & $6987 \pm 57$ & $5976-5807$ & Crassard [23] \\
\hline HDOR 419 (A12 Niv 3 a) & Charcoal & AA64358 & $7016 \pm 52$ & $5981-5845$ & Crassard [23] \\
\hline HDOR 419 (A13 Niv 5 a) & Charcoal & AA64359 & $7017 \pm 52$ & $5982-5845$ & Crassard [23] \\
\hline HDOR 419 (A12 Niv 4 a) & Charcoal & AA64355 & $7022 \pm 52$ & $5983-5847$ & Crassard [23] \\
\hline HDOR 419 (A13 Niv 5 d) & Charcoal & AA64362 & $7042 \pm 53$ & $5990-5844$ & Crassard [23] \\
\hline HDOR 419 (A14 Niv 5) & Charcoal & AA64364 & $7086 \pm 50$ & $6016-5910$ & Crassard [23] \\
\hline Manayzah (K9-017) & Charcoal & AA66685 & $7133 \pm 51$ & $6057-5933$ & Crassard [23] \\
\hline HDOR 419 (A13 Niv 5 e) & Charcoal & AA64363 & $7169 \pm 52$ & $6071-5995$ & Crassard [23] \\
\hline HDOR 419 (A13 Niv 5 c) & Charcoal & AA64361 & $7270 \pm 120$ & $6242-6014$ & Crassard [23] \\
\hline $\begin{array}{l}\text { Khuzmum Rockshelters, } \\
\text { hearth 2000-045-1A-004 }\end{array}$ & Charcoal & AA38543 & $7403 \pm 70$ & $6378-6223$ & $\begin{array}{l}\text { McCorriston } \\
\text { et al. [46] }\end{array}$ \\
\hline $\begin{array}{l}\text { Khuzmum Rockshelters, } \\
\text { hearth 2000-045-1A-009 }\end{array}$ & Charcoal & AA38548 & $7723 \pm 87$ & $6633-6476$ & $\begin{array}{l}\text { McCorriston } \\
\text { et al. [46] }\end{array}$ \\
\hline Manayzah (K9-020) & Charcoal & AA66686 & $8072 \pm 79$ & $7174-6830$ & Crassard [23] \\
\hline
\end{tabular}

proposed, since no datable material has been found, ranging from the very end of the Pleistocene to the Early Holocene.

Finally, the bifacial shaping of foliate pieces in Wadi Wa'shah (Fig. 5) also indicates elaborate knowledge of knapping, foliate pieces being a rather rare phenomenon in Arabia (but well-known on site HDOR 538, [23]). These data would thus suggest the existence of true independent sociocultural complexes in Yemen during the Early/Mid-Holocene.

\subsection{Arrowheads as a major indicator for refining Holocene chronocultural framework}

Arrowheads allow for detailed analyses across the majority of the sites found on the surface and in stratigraphy (for complete typological analyses, see [23], pp. 141-143 and 163-166). Data from stratified Early/ Mid-Holocene sites in Hadramawt, now five in number (HDOR 410 in Wadi Mikhfar, HDOR 419 and HDOR 561 in Wadi Wa'shah, Khuzmum 045-1A and Manayzah in Wadi Sanâ), are given precedence. Three typological groups were distinguished: flat bifacial arrowheads with symmetrical section, arrowheads with trihedral section and arrowheads on flakes or blades. The description of these typological groups led to two principal conclusions.

First, the greater antiquity of the flat bifacial arrowhead type is probable when compared to the trihedral-point type. The flat bifacial points include several subtypes which are distinguished chronologically from the trihedral points and probably attest to production by groups of different traditions since these two typological assemblages are never found together in stratigraphy.

Second, the typological group of the trihedral points (Fig. 3:4,5,8-10) seems to belong to only one chronological episode, around the 6th millennium BC. Trihedral industries are thus interpreted as pertaining to one particular chronocultural 'facies'. The homogeneity of chronometric dates that were obtained from archaeological layers containing trihedral points at four distinct sites confirms this interpretation.

\section{Regional peopling and external influences (environment, topography, cultural traditions) during the Early/Mid-Holocene}

\subsection{Influences from the natural environment: climate and topography}

\subsubsection{Climate and man: general remarks about Southwest Arabia}

In the lowlands, vegetation remained of an arid or semi-arid type during the Arabian Humid Period because of consistently high evaporation rates and 

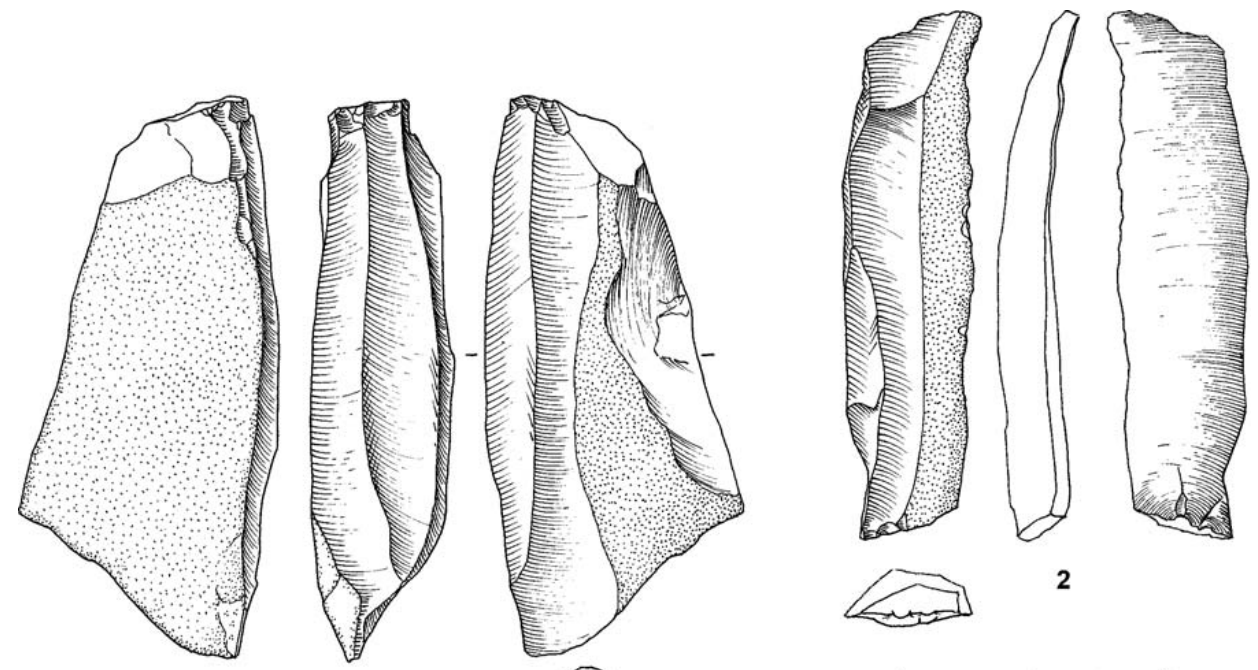

2

1
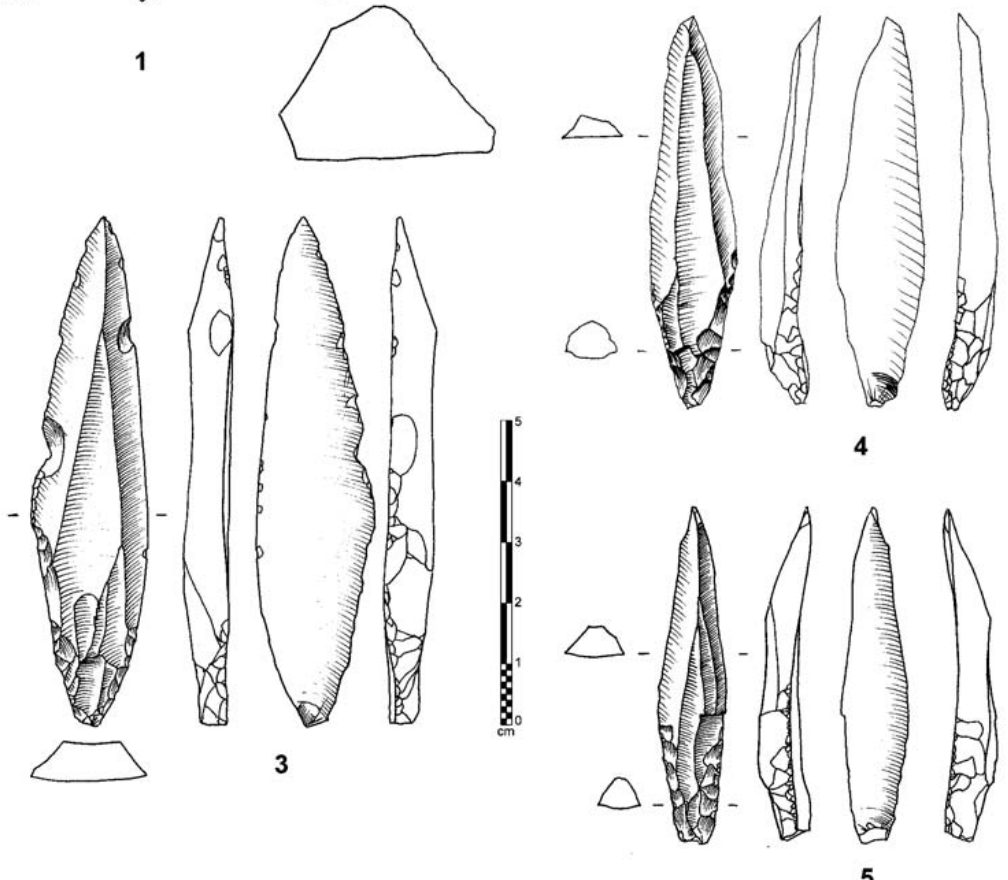

Fig. 4. Wa'shah debitage from Wadi Wa'shah, Hadramawt: 1. core; 2. lateral semi-cortical blade; 3-5: Wa'shah points (drawings J. Espagne \& R. Crassard).

Fig. 4. Débitage Wa'shah du Wadi Wa'shah dans le Hadramawt : 1. nucleus ; 2. lame semi-corticale latérale ; 3-5: pointes de Wa'shah (dessins J. Espagne \& R. Crassard).

the presence of the Yemeni highlands to the west and Hadramawt plateaus to the south/southeast. The broken terrain acted as topographic and ecological barriers to the northward penetration of tropical plants. Moreover, during the Early/Mid-Holocene, the nature of prehistoric occupations of the lowlands seems to be closely related to the availability of water. For example, no human presence can be demonstrated from Ramlat asSab'atayn desert apart from during the periods when lakes were formed and stabilized.

Surface sites, like those at al-Hawa, in Ramlat asSab'atayn, attest to the presence of nomadic or seminomadic communities. Camps built out of stones begin to appear after 6,000 BC in the Arabo-Persian Gulf, whereas permanent sedentary occupations seem to develop from 3,500 BC under climatic conditions of increasing aridification. The adaptive modalities of human groups during this more recent period are centred around complex irrigation systems (falaj in Oman Peninsula and exploitation of the slopes in Southwest Arabia), with food production focused on the exploitation of maritime resources on the coasts and dates and cereals inland [21].

It seems that the climate has played a role in the occupation strategy of prehistoric human groups. It is, however, necessary not to overemphasise its impact on 

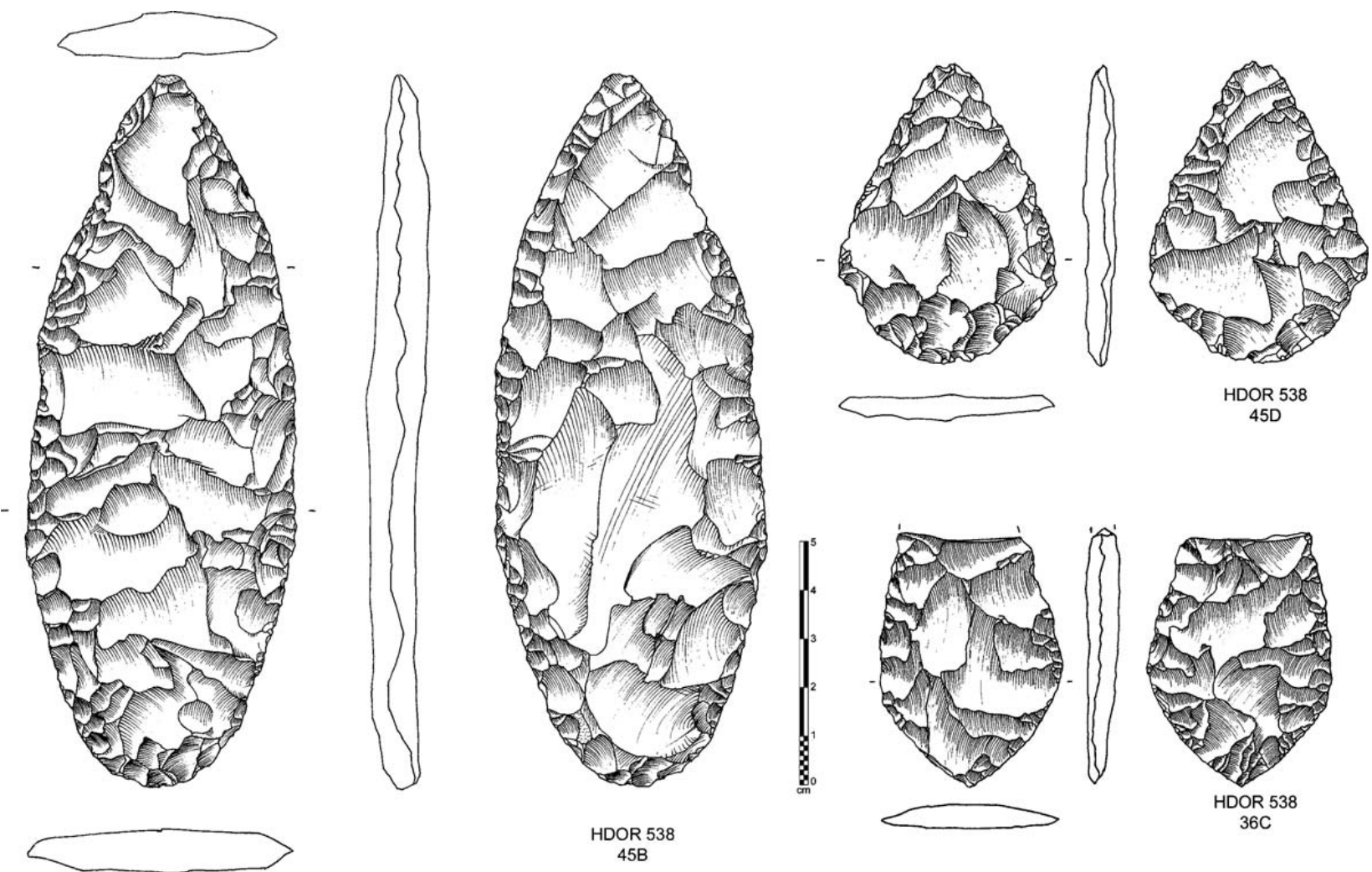

Fig. 5. Foliated bifaces from Wadi Wa'shah, Hadramawt (drawings J. Espagne).

Fig. 5. Bifaces foliacés du Wadi Wa'shah dans le Hadramawt (dessins J. Espagne).

the choices made by human populations, and to consider the adaptability of small groups in arid contexts. It should also be mentioned that a decrease in precipitation does not imply a total lack of water resources [18]. The current Bedouin, who live isolated from the industrialized world, represent the last heirs of a way of life based on seasonal nomadism. Their way of life is disappearing, but this cannot be explained by the extreme aridity or the lack of access to food resources they endure today. It is more for socioeconomic reasons related to our modern world. A good number of Bedouin, particularly in Hadramawt, continue to live a pastoralist way of life based on small livestock (goats, sheep, and camels). They move according to their access to grazing grounds and, because of their low numbers, live under very similar conditions to Early/ Mid-Holocene populations although the climate is much drier.

As Cleuziou and Tosi [20] observe, it is fundamental to distinguish between data obtained from sites with a strong anthropogenic signature and those resulting from little or no human influence. Failing this, "one would condemn oneself... to confuse the action of man and global change, always explaining the first by the second". Climatic variation thus results in a certain number of parameters that guide choices in the occupation of the ground. Climate however is not the exclusive and unavoidable determinant for the development of a way of life. Human adaptability within an environment still constitutes an unforeseeable factor and has been little limited in human evolutionary history.

\subsubsection{Ramlat as-Sab'atayn as a "buffer-zone" between the western Highlands and Hadramawt}

In this section and the next two examples of keyzones in Yemen are examined. They had very different roles according to their topographic characteristics: the central desert of Ramlat as-Sab'atayn; and the Tihama coastal plain along the Red Sea.

Nowadays, Ramlat as-Sab'atayn is one of the most inhospitable sand deserts on the planet. It is thus surprising to find Early/Mid-Holocene occupation remains there. However, climate studies show that this area was probably a passage zone and a "zone of life", thanks to the presence of water, materialized by more or less perennial lakes. It was thus a privileged passageway between the western Highlands and Hadramawt. Two valleys doubtlessly contributed to the diffusion of human and cultural currents: the large Wadi Jawf and 
the mouth of the equally impressive Wadi Hadramawt. Trihedral points are thus found from the Oman Peninsula [12] to the region of Sa'da [37], and along the Jawf-Hadramawt palaeo-river [19], revealing a link between the central desert's bordering areas, at least during the 7 th/6th millennia BC.

What role did the landscape play in the diffusion of the technocomplex based on trihedral and bifacial industries and sometimes by the fluting technique? The presence of water in the Ramlat as-Sab'atayn desert during the Early/Mid-Holocene sustained and facilitated the diffusion of human groups, and thus, cultural traditions like knapping techniques and the types and forms of lithic weapons and tools. Access to the Highlands from the east did not seem to be an insurmountable obstacle. Expansion to the Tihama region towards the west was nevertheless much more problematic. The eastern coast of the Red Sea may then be considered as truly isolated from the more easterly lands, and instead turned towards the African coasts.

\subsubsection{Tihama: a territory apart}

Tihama region is constrained by the escarpment at the western edge of the western Highlands. The few wadis which notch this geographical characteristic could have possibly allowed an opening-up of Tihama during the
Early/Mid Holocene for short periods, thus allowing the intrusion of certain lithic industries, but primarily the barrier supported the development of others which were particular to Tihama. As a matter of fact, obsidian and other volcanic rocks were generally used as soon as the Mid-Holocene, a characteristic rather circumscribed within Tihama. From the 2nd millennium BC, Tihama finds a place in trading with easterly regions with a quasisystematic production of geometric microliths [23].

\subsubsection{A topographic structural influence}

The examples of Tihama as an isolated zone and Ramlat as-Sab'atayn desert as a "buffer-zone" mark the important role played by topography, and the landscape and climate in general, in the diffusion and development of lithic industries and the groups who produced them. Thus potential zones of isolation, connection and separation are distinguished according to these parameters. Fig. 6 shows these zones and the comparative possibilities for the connections of an area, with more or less degree of importance. There are then some major zones of connection such as Wadi Jawf or Wadi Hadramawt, some zones relatively isolated from the inland areas like Tihama and some zones of separation, like the large western escarpment of the western Highlands.

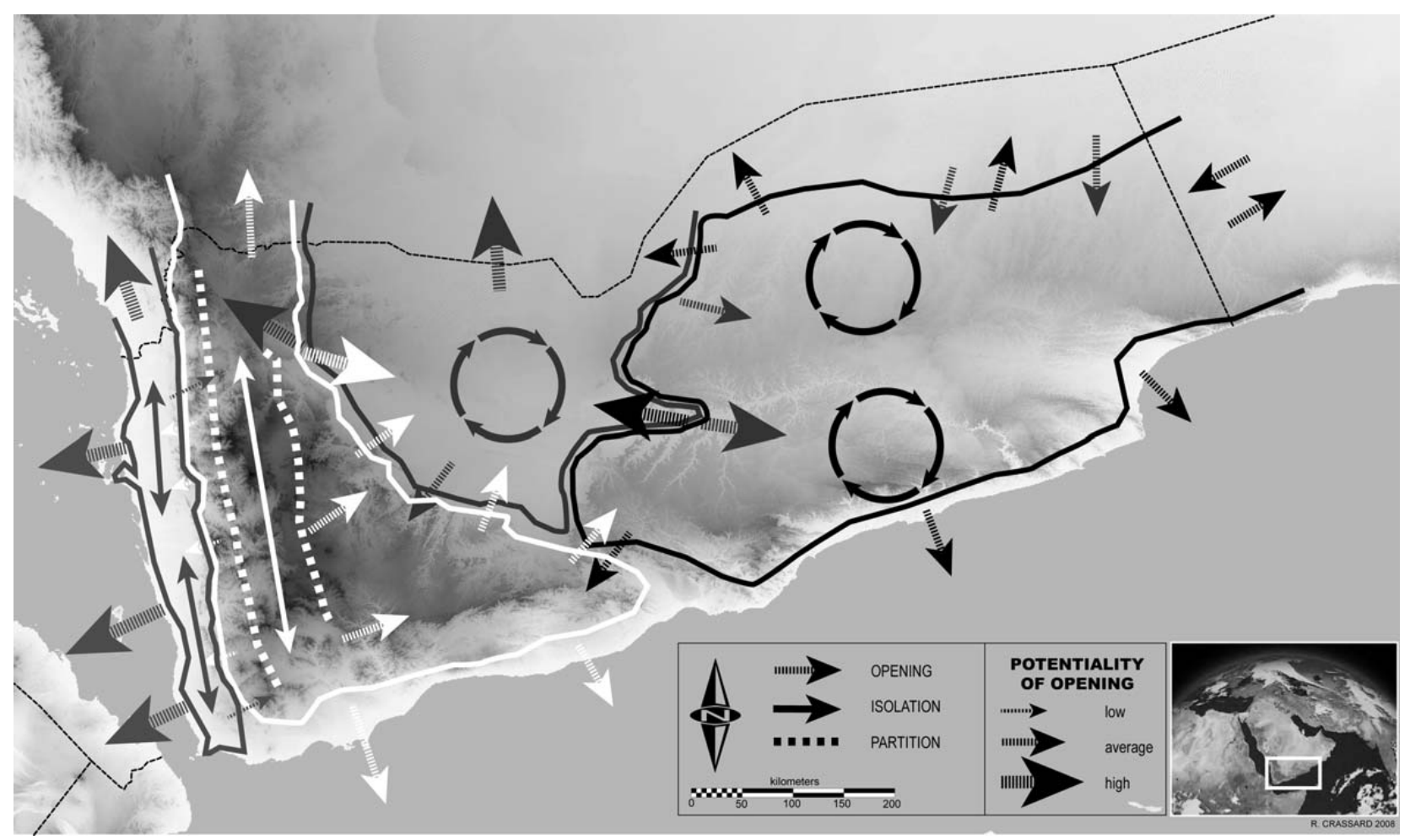

Fig. 6. Potential zones of isolation, connection and separation in Yemen during the Early/Mid-Holocene.

Fig. 6. Zones potentielles d'isolation, d'ouverture et de séparation au Yémen pendant l'Holocène ancien/moyen. 


\subsection{Influences from the cultural environment: the neighboring regions}

\subsubsection{Influences from the north?}

South Arabia, and particularly the Yemeni territory, has long been considered a "satellite area" or "passive margin" under the influence of the Levantine cultures. This consideration is mainly influenced by greater archaeological knowledge advancement in the Levant than the Arabian Peninsula, thanks to a much wider archaeological research investment in the former region in terms of people and time. Nevertheless, explaining the nature and development of South Arabian prehistoric cultures solely from a Levantine perspective is problematic, especially when influenced by prejudicial views of South Arabia as an "elephants cemetery" [34], or a "cul-de-sac" of the Levantine diffusion for the Pleistocene as well as the Holocene [22]. The scarcity or absence of stratified sites in Yemen however acted for a long time in favor of these prejudices.

Chronological terminology suffered from these comparisons, and the Yemeni "Neolithic" appeared in the nomenclature as part of the "logical" periodisation of any prehistoric civilization. On which criteria was this appellation based?

Initially, PrePottery Neolithic societies (PPNA, PPNB and PPNC) from the Levant used the pressure retouch technique in the creation of lithic tools, and particularly in arrowhead manufacture. While having a Neolithic way of life based on a production economy, these populations did not yet know ceramics, or at least did not produce any. This situation was connected rather clearly with the one observed on Yemeni surface sites: pressure shaped arrowheads and absence of pottery. A missing key element was consequently neglected: no proof of any production economy had been clearly discovered in South Arabia. The comparison thus stopped with typological considerations. Moreover, the comparisons with the Levant did not take into consideration the very common laminar component in Levantine assemblages (including naviform cores and pressure debitage), which was quasi-absent in those from Arabia. Also, fluting and trihedral points are not found in the Levant.

Thus, without evidence to the contrary, we cannot detect any particular link in terms of typology, technology, artistic representations, symbolic system, etc. during the Early/Mid-Holocene between the Levant and Southwest Arabia.

\subsubsection{Interrelationships with the east?}

Comparison with Holocene sites from the eastern regions outside Yemen is definitely more relevant than those with the Levant. In this regard, recent syntheses by Cleuziou [18] and Charpentier [12] reveal close links between certain South Arabian Holocene populations.

Certain truly Neolithic populations are attested within the Sultanate of Oman, in particular at many coastal sites [4,10,11,13-15,21,55]. A comparison of lithic industries attests close links with industries from Yemen.

The presence of industries on flakes and blades, like the Fasad points [9] or the Wa'shah points [24], is an interesting fact underlining a laminar conceptualization in lithic arrowhead production. It is a first common point which may appear at the beginning of the Holocene.

Trihedral points, typical at the beginning of the MidHolocene, are found from the Oman Peninsula's eastern regions across to the Yemeni Western Highlands. They ultimately represent a technical and typological link which most probably gave way to the apparently slightly later fluting technique, especially in Yemen and to a lesser extent in Oman and the United Arab Emirates $[11,16]$.

These comparative data reveal technical and typological complexes that lie within a chronocultural framework that is being constantly updated by new stratified sites discoveries. Some real "cultural waves" have thus existed in South Arabia, and without evidence of external origins, these very probably suggest endemic development.

\subsubsection{Interactions between Africa and Southwest Arabia beyond the Tihama region?}

The archaeology of the East African Holocene is still far from understood. Very strong links are known for recent prehistory (3rd/2nd to 1 st millennium $\mathrm{BC}$ ) on both sides of the Red Sea coasts (obsidian trade, megalithism, rockart [39]). They are on the other hand more difficult to highlight for the older periods. Isolation of the coastal plain of Tihama has been shown for the Early/Mid-Holocene, and few elements therefore allow suggestion of interactions between Africa and the regions located to the east of Tihama. The question of how these two areas were connected thus remains unanswered.

\subsubsection{Arabia as a pole of influence?}

If Southwest Arabia is really located "at the margins of the large Neolithic cradles" [35], and in particular of the Fertile Crescent, it is probable that this region "took another way" [18]. Yemen 'Neolithisation' seems to occur tardily, as in the rest of South Arabia, with a way of life centered around a production economy from the 
period known as the "Bronze Age" around the second half of the 4th millennium BC.

That does not preclude however the presence of groups of pastoralists/hunter-gatherers dated to the 6th millennium BC, whose first indices, in Manayzah in particular, will be confirmed by the study of the faunal remains [43]. Is it possible at that time to speak about a "specific pole" of influence for Yemen? If this expression seems rather strong, we may prefer to speak of an "endemic development area" that one can particularly detect in South Arabian lithic industries. Those unquestionably reveal common stylistic and technique objectives, which do not find, for the time being, any comparative referent in the neighbouring regions.

\section{Territorial occupations and Yemeni particularities during the Early/Mid-Holocene}

\subsection{Occupation of the Tihama Red Sea coastal plain}

The Arabian Humid Period was favourable to settlements close to mangrove environments (for example the site of ash-Shumah [8]). During this period, these milieus could develop and provide important food resources, like molluscs, to populations likely lacking much mobility.

The end of the Humid Period sees a progressive aridification, a slight lowering of the sea level and a partial retreat of typical Early Holocene mangrove habitats. These observations are confirmed by the evolution of river deltas and by coastal site distributions moving inland to the east after the $7 \mathrm{th} / 6$ th millennia $\mathrm{BC}$. From the 4th millennium BC, sites are close again to coasts and wadi edges, revealed by intensification of fishing activities and by remains of domesticated animals, whereas evidence of a production economy is still visible but to a lesser extent [39].

In parallel, the coastal communities are characterised by use of obsidian originating in Africa from the 6th to the 1st millennium BC. These interrelationships suggest a more or less developed and intensive navigation, and the ichthyofaunal remains attest to high levels of seafishing, at least for the most recent times.

\subsection{Occupation in the western Highlands}

Few data allow the proposal of a preliminary picture of Early Holocene occupation in the Yemeni Highlands. At that time, a certain environmental stability was present, which did not require particular modification of the landscape. Human impact on the environment was thus negligible and few archaeological indices remain from this period, these having gradually been destroyed by the successive and intensive later occupations. EarlyHolocene palaeosols in the Highlands show organic stability [58] indicating that environment was sufficiently stable to replenish the natural resources even if some degree of overexploitation existed at that time.

\subsection{Occupation in Ramlat as-Sab'atayn central desert}

The large central sand desert is the geographical component that has been most dependent on the climate during Yemen's regional human occupation history. With its hyperaridity associated with the difficulty of crossing it, Ramlat as-Sab'atayn is not a preferred place for human settlement. The desert did however play an important role as a probable "buffer-zone" between eastern and western regions. Diffusion of trihedral arrowhead industries is attested there. The presence of lakes, and thus favorable conditions for occupation or crossing, improved human preference for the place during the Arabian Humid Period. Grinding tools were discovered there [38] and are good indicator towards positing a certain perennial habitation of the sites along the lakes' edges.

\subsection{Occupation in Hadramawt plateaus region}

The Hadramawt plateaus are the best known area for Yemeni prehistory. It is already possible to propose a model of occupation of the various components of the landscape, according to surveys carried out from wadi beds to plateau tops [26].

Wadi beds are not favorable for conservation of archeological sites. Scouring by floods, often violent in these contexts, causes destruction to the layers. However, the formation of large terraces via silt accumulation could have sealed prehistoric sites. Only the Manayzah site (Wadi Sanâ) is an exception, since it may have been very well preserved thanks to its slightly shifted position relative to the principal wadi course.

Some terraces are located between 20 and $50 \mathrm{~m}$ above the wadi beds. They shelter a high density of prehistoric layers, but are very often deflated, delivering Middle Paleolithic to Holocene industries. The lithic raw material is present in the direct vicinity but is often of poor quality. However, excavation at HDOR 410 site [23]) proves that the topographic context of these terraces can sometimes preserve stratigraphic deposits.

Finally, raw material is abundant at the top of the plateaus. Holocene sites are numerous, mainly in the vicinity of lithic raw material. Stratigraphic accumula- 
tion could be conserved when sites were in contexts protected from the erosive phenomena, such as for instance HDOR 419 or HDOR 561 [26].

\section{Synthesis}

Two occupation models can thus be proposed: a diffusionist model seeing a Levantine influence in Arabian lithic industries, and a second model privileging an endemic development of Early/Mid-Holocene huntergatherers societies leading to some of the very first elements of a Neolithic way of life, like pastoralism. These two models both have their credibility, perhaps dependent on the period under examination. The diffusionist model is however not attested to by archaeological vestiges and thus remains a purely theoretical one. It represents a search for external influences in the attempt to explain absent elements in Yemen, and represents the "escape" generated by generalization in archaeological science, which inevitably leads to diffusionist conclusions [17].

The description of an alternative model has important theoretical interest, and fits more broadly into global questions about the place of peripheral zones in comparison with the "classical Neolithic centers" of innovation and invention. The research perspectives that the Arabian Peninsula offers are therefore increasingly important in attempting to better comprehend the evolution of hunter-gatherers societies.

Concerning the modalities of occupations throughout the Holocene period, the influence of the climate was important but not inevitably decisive. The humid periods certainly contributed in supporting displacements and relations between various groups. On the other hand, the drier periods do not necessarily have to have impelled human groups to leave the area. They could have found refuge zones like mountains and high plateaus, or they might have decreased the number of individuals within the group, in order to better profit from food access. Trading could also have been intensified during these periods, between groups which had difficulty accessing resources and those more capable of providing for their own needs.

Holocene occupations were thus partly controlled by access to resources (including lithic ones, but mainly food and water). The Holocene inhabitants however showed an ability to adapt themselves to their sometimes extreme environment, which is characteristic of many people from desert regions, being very cold or very warm. Then, if the image of a rather isolated area is not too distant from an archaeological reality at certain times, it is fundamental not to consider it as depopulated and without interest for the comprehension of regional prehistory on a wider scale.

\section{Acknowledgements}

I gratefully acknowledge the organizers of the international conference on the history of climate and environmental deserts of Africa and Arabia, particularly Anne-Marie Lézine for her invitation and Serge Cleuziou, as well as the French Academy of Sciences in Paris.

The work described from Hadramawt has been undertaken within two research projects. I am happy to warmly thank the RASA Project directors: Joy McCorriston, Eric Oches, Abdulaziz bin Aqil, and also the French Archaeological Mission in Jawf-Hadramawt directors: Michel Mouton, Frank Braemer, Anne Benoist.

For their comments and general discussion about South Arabian prehistory, I gratefully acknowledge the help of Pierre Bodu, Vincent Charpentier, Marie-Louise Inizan, Edward J. Keall, Lamya Khalidi, Louise Martin, Joy McCorriston, Michael D. Petraglia, Jérémie Schiettecatte. I finally thank the Fondation Fyssen for providing financial support for my stay in Cambridge, and I thank the LCHES staff for their warm welcome, especially Michael Haslam for re-reading the English version of this text.

\section{References}

[1] H.A. Amirkhanov, Research on the Palaeolithic and Neolithic of Hadramaut and Mahra, Arabian Archaeology and Epigraphy 5 (1994) 217-228.

[2] H.A. Amirkhanov, Stone Age of South Arabia, Nauka, Moscow, 2006 (in Russian).

[3] O. Bar-Yosef, A. Belfer-Cohen, From Africa to Eurasia - Early dispersals, Quaternary International 75 (2001) 19-28.

[4] J.-F. Berger, S. Cleuziou, G. Davtian, M. Cattani, F. Cavulli, V. Charpentier, M. Cremaschi, J. Giraud, Le Ja'alan (Oman) à l'Holocène Moyen, impact sur l'évolution des paléomilieux littoraux et les stratégies d'adaptation des communautés humaines, Paléorient 31 (1) (2005) 46-63.

[5] A. Beyin, The Bab al Mandab vs. The Nile-Levant: an appraisal of the two dispersal routes for Early Modern Humans out of Africa, African Archaeological Review 23 (2006) 5-30.

[6] S.J. Burns, D. Fleitmann, A. Matter, U. Neff, A. Mangini, Speleothem evidence from Oman for continental pluvial events during interglacial periods, Geology 29 (7) (2001) 623-626.

[7] G. Caton-Thompson, Geology and archaeology of the Hadramaut, Southern Arabia, Nature 142 (1938) 139-142.

[8] M. Cattani, S. Bökönyi, Ash-Shumah: an Early Holocene settlement of desert hunters and mangrove foragers in the Yemeni Tihamah, in: S. Cleuziou, M. Tosi, J. Zarins (Ed.), Essays on the Late Prehistory of the Arabian Peninsula, Serie Orientale Roma vol. XCIII, IsIAO, Rome, 2002, pp. 31-53. 
[9] V. Charpentier, Entre sables du Rub' al-Khali et mer d'Arabie, Préhistoire récente du Dhofar et d'Oman: les industries à pointes de « Fasad », Proceedings of the Seminar for Arabian Studies 26 (1996).

[10] V. Charpentier, Les industries lithiques de Ra's al-Hadd, Proceedings of the Seminar for Arabian Studies 31 (2001) $31-45$.

[11] V. Charpentier, From the Gulf to Hadramawt: Fluting and Plunging Processes in Arabia, in : D.T. Potts, H. al-Nabooda, P. Hellyer (Eds.), First International Conference on Emirates Archaeology, Trident Press, London, 2003, pp. 66-71.

[12] V. Charpentier, Trihedral points: a new facet to the "Arabian Bifacial Tradition", Proceedings of the Seminar for Arabian Studies 34 (2004) 53-66.

[13] V. Charpentier, M. Cremaschi, F. Demnard, Une campagne archéologique sur un site côtier du Ja'lan : al-Haddah (BJD1) et sa culture matérielle, Proceedings of the Seminar for Arabian Studies 27 (1997) 99-111.

[14] V. Charpentier, O. Blin, M. Tosi, Excavations at as-Suwayh SWY-2 and the beginning of Ocean exploitation in the Ja'lan, Proceedings of the Seminar for Arabian Studies 28 (1998) 21-38.

[15] V. Charpentier, D.E. Angelucci, S. Méry, J.-F. Saliège, Autour de la mangrove morte de Suwayh, l'habitat VI-V millénaires de Suwayh SWY-11, Sultanat d'Oman, Proceedings of the Seminar for Arabian Studies 30 (2000).

[16] V. Charpentier, M.-L. Inizan, Diagnostic evidence on fluting in the Old-World: The Neolithic projectile points of Arabia, Lithic Technology 27 (2002) 39-46.

[17] S. Cleuziou, De la Caspienne à la Mer Rouge, éléments pour la justification d'une archéologie exotique, Thèse d'habilitation à diriger des recherches, université Paris 1, Paris, 1999.

[18] S. Cleuziou, Pourquoi si tard ? Nous avons pris un autre chemin. L'Arabie des chasseurs-cueilleurs de l'Holocène au début de l'Âge du Bronze, in : J. Guilaine (Ed.), Aux marges des grands foyers du Néolithique, périphéries débitrices ou créatrices ?, Errance Editions, Paris, 2004, pp. 123-148.

[19] S. Cleuziou, M.-L. Inizan, B. Marcolongo, Le peuplement pré- et protohistorique du système fluviatile fossile du Jawf-Hadramawt au Yémen (d'après l'interprétation d'images satellite, de photographies aériennes et de prospections), Paléorient 18 (2) (1992) $5-28$.

[20] S. Cleuziou, M. Tosi, Hommes, climats et environnements de la Péninsule arabique à l'Holocène, Paléorient 23 (2) (1998) 121135.

[21] S. Cleuziou, M. Tosi, In the shadow of the ancestors: The prehistoric foundations of the early Arabian civilization in Oman, Ministry of Heritage and Culture of the Sultanate of Oman, Muscat, 2007.

[22] C.S. Coon, Southern Arabia: a Problem for the Future, Papers of the Peabody Museum of American Archaeology and Ethnology 20 (1943) 187-220.

[23] R. Crassard, La préhistoire du Yémen, diffusions et diversités locales, à travers l'étude d'industries lithiques du Hadramawt, BAR International Series 1842, Archaeopress, Oxford, 2008.

[24] R. Crassard, The "Wa "shah method": an original laminar debitage from Hadramawt, Yemen, Proceedings of the Seminar for Arabian Studies 38 (2008) 3-14.

[25] R. Crassard, Middle Paleolithic in Arabia: the view from the Hadramawt region, Yemen, In: M.D. Petraglia, J.I. Rose (Eds.), The Evolution of Human Populations in Arabia, Springer Academic Publishers, New York, in press.
[26] R. Crassard, P. Bodu, Préhistoire du Hadramawt (Yémen): nouvelles perspectives, Proceedings of the Seminar for Arabian Studies 34 (2004) 67-84.

[27] R. Crassard, L. Khalidi, De la pré-Histoire à la Préhistoire au Yémen, des données anciennes aux nouvelles expériences méthodologiques, Chroniques Yéménites 12 (2005) 1-18.

[28] R. Crassard, J. McCorriston, E. Oches, A. bin 'Aqil, J. Espagne, M. Sinnah, Manayzah, early to mid-Holocene occupations in Wâdî Sanâ, Proceedings of the Seminar for Arabian Studies 36 (2006) 151-173.

[29] R. Crassard, H. al-Aidarûs, Kh. al-Hadj, G. Bruley-Chabot, V. Léa, C. Thiébaut, A sixth millennium site BC in Hadramawt: HDOR 419, Proceedings of the Seminar for Arabian Studies 39, in press.

[30] R. Derricourt, Getting "Out of Africa": sea crossings, land crossings and culture in the hominin migrations, Journal of World Prehistory 19 (2005) 119-132.

[31] J.S. Field, M.M. Lahr, Assessment of the Southern Dispersal: GIS-based analyses of potential routes at Oxygen Isotopic Stage 4, Journal of World Prehistory 19 (1) (2005) 1-45.

[32] D. Fleitmann, S.J. Burns, M. Mundelsee, U. Neff, J. Kramers, A. Mangini, A. Matter, Holocene forcing of the Indian monsoon recorded in a stalagmite from Southern Oman, Science 300 (2003) 1737-1739.

[33] P. Forster, S. Matsumura, Did early humans go north or south? Science 308 (2005) 965-966.

[34] G. Garbini, Preistoria e protostoria, in : S. Noja (Ed.), I primi Arabi, Jaca Book, Milan, 1994, pp. 11-18.

[35] J. Guilaine, Aux marges des grands foyers du Néolithique, Errance Éditions, Paris, 2004.

[36] M.-L. Inizan, L. Ortlieb, Préhistoire dans la region de Shabwa au Yémen du sud (R. D. P. Yémen), Paléorient 13-1 (1987) $5-22$.

[37] M.-L. Inizan, M. Rachad, Art rupestre et peuplements préhistoriques au Yémen, CEFAS, Sana'a, 2007.

[38] M.-L. Inizan, A.-M. Lézine, B. Marcolongo, J.-F. Saliège, C. Robert, F. Werth, Paléolacs et peuplements holocènes du Yémen: le Ramlat as-Sab'atayn, Paléorient 23 (2) (1998) 137-149.

[39] L. Khalidi, Settlement, Culture-Contact and Interaction along the Red Sea Coastal Plain, Yemen: The Tihamah cultural landscape in the late prehistoric period, 3000-900 BC, PhD dissertation, University of Cambridge, UK, 2006, 396 p.

[40] M.M. Lahr, R. Foley, Towards a theory of modern human origins: geography, demography, and diversity in recent human evolution, Yearbook of Physical Anthropology 41 (1998) 137-176.

[41] A.-M. Lézine, J.-F. Saliège, R. Mathieu, T.L. Tagliatela, S. Méry, V. Charpentier, S. Cleuziou, Mangroves of Oman during the Late Holocene: climatic implications and impact on human settlements, Vegetation History and Archaeobotany 11 (3) (2002) 221-232.

[42] A.-M. Lézine, J.-J. Tiercelin, C. Robert, J.-F. Saliège, S. Cleuziou, M.-L. Inizan, F. Braemer, Centennial to millennial-scale variability of the Indian monsoon during the Early Holocene from a sediment, pollen and isotope record from the desert of Yemen, Palaeogeogr., Palaeoclimatol., Palaeoecol. 243 (2007) 235-249.

[43] L. Martin, J. McCorriston, R. Crassard, Early Arabian pastoralism at Manayzah in Wâdî Sanâ, Hadramawt, Proceedings of the Seminar for Arabian Studies 39, in press.

[44] H.A. McClure, The Arabian Peninsula and Prehistoric Populations, Field Research Projects, Coconut Grove, Miami, 1971. 
[45] H.A. McClure, Radiocarbon chronology of Late Quaternary lakes in the Arabian Desert, Nature 263 (1976) 755.

[46] J. McCorriston, E. Oches, D.E. Walter, K.L. Cole, Holocene paleoecology and prehistory in Highland Southern Arabia, Paléorient 28 (1) (2002) 61-88.

[47] M.D. Petraglia, The Lower Paleolithic of the Arabian Peninsula: occupations, adaptations, and dispersals, Journal of World Prehistory 17 (2) (2003) 141-179.

[48] M.D. Petraglia, A. Alsharekh, The Middle Palaeolithic of Arabia: Implications for modern human origins, behaviour and dispersals, Antiquity 77 (2003) 671-684.

[49] W.L. Prell, J.E. Kutzbach, Monsoonal variability over the past 150000 years, J. Geophys. Res. 82 (1987) 8411-8425.

[50] N. Roberts, H.E. Wright Jr., Vegetational, lake-level and climatic history of the Near East and Southwest Asia, in : H.E. Wright, Jr., J.E. Kutzbach, T. Webb, W.F. Ruddiman, F.A. StreetPerrott, P.J. Bartleint (Eds.), Global Climates Since the Last Glacial Maximum, University of Minnesota Press, Minnesota, 1993, pp. 194-220.

[51] J.I. Rose, Among Arabian Sands: Defining the Palaeolithic of Southern Arabia. PhD dissertation, Southern Methodist University, Dallas, 2006.
[52] P. Sanlaville, Changements climatiques dans la Péninsule arabique durant le Pléistocène supérieur et l'Holocène, Paléorient 18 (1) (1992) 5-25.

[53] P. Sanlaville, Le Moyen-Orient arabe : Le milieu et l'homme, Armand Colin, Paris, 2000.

[54] F. Sirocko, M. Sarnthein, H. Erlenkeuser, H. Lange, M. Arnold, J.-C. Duplessy, Century-scale events in monsoonal climate over the past 24,000 years, Nature 364 (1993) 322-324.

[55] D. Usai, New Prehistoric sites along the Omani coast from Ra's al-Hadd to Ra's al-Jins, Arabian Archaeology and Epigraphy 11 (2000) 1-8.

[56] G.W. Van Beek, G.H. Cole, G.H. Jamme Aluf, An archaeological reconnaissance in Hadramaut: a preliminary report, Annual Report of the Smithsonian Institute, 1963.

[57] D.E. Walter, J. McCorriston, E. Oches, Shumlya GBS - an Arabian Bifacial Tradition assemblage from Hadramawt province, Yemen, Neo-Lithics 2-3/00 (2000) 12-14.

[58] T.J. Wilkinson, Holocene environments of the high plateau, Yemen. Recent geoarchaeological investigations, Geoarchaeology 12 (1997) 833-864.

[59] T.J. Wilkinson, Archaeological Landscapes of the Near East, The University of Arizona Press, Tucson, 2003. 